\title{
Epigenetic regulation of DNA base excision repair during ageing and dietary restriction
}

\author{
J. Górniak ${ }^{1}$, S. A. S. Langie ${ }^{1}$, K. M. Cameron ${ }^{2}$, T. von Zglinicki ${ }^{2}$, J. Mann $^{3}$, D. M. Pachen ${ }^{4}$, \\ R. W. L. Godschalk ${ }^{4}$ and J. C. Mathers ${ }^{1,2}$ \\ ${ }^{1}$ Centre for Brain Ageing and Vitality, Human Nutrition Research Centre and ${ }^{2}$ Centre for Integrated Systems Biology \\ of Ageing and Nutrition, Institute for Ageing and Health, Newcastle University, NE4 5PL, ${ }^{3}$ Institute of Cellular Medicine, \\ Newcastle University, NE2 $2 N N$ and ${ }^{4}$ Department of Health and Risk Analysis and Toxicology, Maastricht University, \\ The Netherlands
}

Base excision repair (BER) is the primary mechanism used to fix oxidative damage to DNA. However BER efficiency declines with age ${ }^{(1,2)}$. To determine whether epigenetic events contribute to the ageing process through deregulation of BER gene expression we quantified DNA methylation and histone acetylation at BER-gene promoters (Oggl and Apex) and BER repair activity in ageing and dietary restricted (DR) mice.

We measured promoter methylation by pyrosequencing in brain and livers from ad libitum (AL) and 40\% DR mice at 3, 12, 24 and 30 months of age ( $n=5-7 /$ group). Oggl promoter methylation decreased with age in the liver $(p=0.018)$ and brain $(p=0.016)$ and DR reduced $O g g 1$ methylation $(p=0.014)$ in the brain. At 30 mo, we observed a 2.5 fold enrichment in histone 4 acetylation as measured by the ChIP assay in liver Oggl promoter $(p=0.004)$ and a 2 fold enrichment at $O g g 1(p=0.02)$ and Apex promoters $(p=0.031)$ in the brain. Ogg1 expression in the liver decreased by $40 \%$ with age and DR $(p=0.0031)$ and with DR only in the brain $(p=0.002)$. Apex expression did not change with age but was lower in DR animals $(p=0.003)$. A comet-based in vitro assay for BER incision activity ${ }^{(3)}$ revealed no significant changes in either tissue. 8-oxoguanine lesions measured by HPLC-ECD decreased with age $(p<0.001)$ in the liver but not in the brain.

Table 1. Summary of results from the liver

\begin{tabular}{|c|c|c|c|c|c|c|c|c|}
\hline \multirow[b]{2}{*}{ Group } & \multicolumn{2}{|c|}{ Methylation (\%) } & \multicolumn{2}{|c|}{ Acetylation (fold enrichment) } & \multicolumn{2}{|c|}{ Expression $\left(2^{\wedge}-\Delta \mathrm{Ct}\right)$} & \multirow{2}{*}{$\begin{array}{c}\text { Repair (calculated from } \\
\text { Tail Intensity) }\end{array}$} & \multirow{2}{*}{$\begin{array}{c}\text { Oxidative damage } \\
\text { (8-oxodG/10E6dG) }\end{array}$} \\
\hline & Ogg1 & Apex & Ogg1 & Apex & Oggl & Apex & & \\
\hline 3AL & $1.76 \pm 0.1$ & $2.26 \pm 0.6$ & $0.86 \pm 0.1$ & $1.32 \pm 0.4$ & $0.0055 \pm 0.0002$ & $0.024 \pm 0.002$ & $15.2 \pm 2.4$ & $47.3 \pm 2.6$ \\
\hline 30AL & $1.19 \pm 0.1$ & $1.49 \pm 0.2$ & $0.73 \pm 0.1$ & $1.30 \pm 0.3$ & $0.0051 \pm 0.0005$ & $0.027 \pm 0.004$ & $15.7 \pm 2.5$ & $31.3 \pm 1.5$ \\
\hline 30DR & $1.11 \pm 0.1$ & $1.75 \pm 0.3$ & $2.59 \pm 0.5$ & $0.52 \pm 0.1$ & $0.0031 \pm 0.0002$ & $0.016 \pm 0.001$ & $15.0 \pm 2.5$ & $45.0 \pm 1.6$ \\
\hline
\end{tabular}

Table 2. Summary of results from the brain

\begin{tabular}{|c|c|c|c|c|c|c|c|c|}
\hline \multirow[b]{2}{*}{ Group } & \multicolumn{2}{|c|}{ Methylation (\%) } & \multicolumn{2}{|c|}{ Acetylation (fold enrichment) } & \multicolumn{2}{|c|}{ Expression $\left(2^{\wedge}-\Delta \mathrm{Ct}\right)$} & \multirow{2}{*}{$\begin{array}{c}\text { Repair calculated from } \\
\text { Tail Intensity) }\end{array}$} & \multirow{2}{*}{$\begin{array}{l}\text { Oxidative damage } \\
\text { (8-oxodG/0E6dG) }\end{array}$} \\
\hline & Oggl & Apex & Oggl & Apex & Oggl & Apex & & \\
\hline 3AL & $1.28 \pm 0.04$ & $1.64 \pm 0.1$ & $0.50 \pm 0.1$ & $0.48 \pm 0.1$ & $0.016 \pm 0.003$ & $0.083 \pm 0.010$ & $3.0 \pm 1.1$ & $12.2 \pm 0.4$ \\
\hline 30AL & $1.07 \pm 0.1$ & $1.49 \pm 0.3$ & $1.27 \pm 0.3$ & $1.15 \pm 0.3$ & $0.012 \pm 0.002$ & $0.054 \pm 0.006$ & $2.7 \pm 1.4$ & $13.8 \pm 2.8$ \\
\hline 30DR & $0.81 \pm 0.1$ & $1.36 \pm 0.1$ & $0.41 \pm 0.2$ & $0.35 \pm 0.2$ & $0.014 \pm 0.001$ & $0.083 \pm 0.008$ & $4.9 \pm 0.8$ & $29.0 \pm 12.8$ \\
\hline
\end{tabular}

In summary, our data suggest that epigenetic processes may contribute to transcriptional changes in BER-related genes during ageing and with DR.

This work was funded by the Research Councils through the Lifelong Health and Wellbeing Initiative.

1. Intano GW, Cho EJ, McMahan et al. (2003) J Gerontol A Biol Sci Med Sci 58, B205-B211.

2. Swain U \& Rao KS (2012) Mech Ageing Dev 133, 186-194.

3. Langie SAS, Cameron KM, Waldron KJ et al. (2011) Mutagenesis 26, 461-71. 